Association for Information Systems

AIS Electronic Library (AISeL)

Wirtschaftsinformatik Proceedings 2011

Wirtschaftsinformatik

2011

\title{
Technology Adoption by Elderly People - An Empirical Analysis of Adopters and Non-Adopters of Social Networking Sites
}

Christian Maier

Otto-Friedrich University Bamberg, christian.maier@uni-bamberg.de

Sven Laumer

Otto-Friedrich University Bamberg, sven.laumer@uni-bamberg.de

Andreas Eckhardt

Goethe-University Frankfurt am Main, eckhardt@wiwi.uni-frankfurt.de

Follow this and additional works at: http://aisel.aisnet.org/wi2011

\section{Recommended Citation}

Maier, Christian; Laumer, Sven; and Eckhardt, Andreas, "Technology Adoption by Elderly People - An Empirical Analysis of Adopters and Non-Adopters of Social Networking Sites" (2011). Wirtschaftsinformatik Proceedings 2011. 25.

http://aisel.aisnet.org/wi2011/25

This material is brought to you by the Wirtschaftsinformatik at AIS Electronic Library (AISeL). It has been accepted for inclusion in Wirtschaftsinformatik Proceedings 2011 by an authorized administrator of AIS Electronic Library (AISeL). For more information, please contact elibrary@aisnet.org. 


\section{Technology Adoption by Elderly People - An Empirical Analysis of Adopters and Non-Adopters of Social Networking Sites}

\author{
Christian Maier \\ Centre of Human Resources \\ Information Systems \\ Otto-Friedrich University Bamberg \\ christian.maier@uni-bamberg.de
}

\author{
Sven Laumer \\ Centre of Human Resources \\ Information Systems \\ Otto-Friedrich University Bamberg \\ sven.laumer@uni-bamberg.de
}

\author{
Andreas Eckhardt \\ Centre of Human Resources \\ Information Systems \\ Goethe-University Frankfurt am Main \\ eckhardt@wiwi.uni-frankfurt.de
}

\begin{abstract}
This research paper analyzes the impact of attitudinal, control and normative beliefs on the intention to use social network sites (SNS) by people older than 50. Using the Model of Adoption of Technology in Households (MATH) and the data of 115 social network site adopters and 53 non-adopters it can be shown that the intention of adopters and non-adopters has been influenced by different reasons. Perceived Ease of Use and Normative Beliefs have only a significant impact for adopters. Moreover, this research paper unfolds Fear of Technology as a strong influence factor for non-adopters in regard not to use SNS in their daily routine. The paper concludes with a discussion of an age-sensitive design of SNS in order to address the digital divide.
\end{abstract}

\section{Keywords}

Adoption, Non-Adoption, MATH, Elderly People, Social Network Sites

\section{INTRODUCTION}

Due to new information and communication technologies, organizations can simplify the work of their employees, which is the largely overlooked perspective in IS research [21]. In addition households could integrate these technical innovations within their daily routine to handle ordinary or uncommon tasks within short periods of time. One essential renewal in the last years was the introduction of Social Network Sites (SNS), which can be defined as "online shared interactive spaces, in which a group of people use a repertoire of technological features (forums, newsgroups, messaging) to carry out a wide range of social interaction" ([42]; [44]). Actual, a lot of different SNS compete to be the market leader, however, at the moment Facebook [30], with more than 400 million active users, is the most used SNS around

$10^{\text {th }}$ International Conference on Wirtschaftsinformatik, $16^{\text {th }}-18^{\text {th }}$ February 2011, Zurich, Switzerland the world. On the other side, certain countries as Germany [66] have other online communities with a similar high number of users. In Germany, over 30 Million people are members of social communities on the internet [10].

These users can inform all their friends and acquaintances with just one message, communicate or chat to maintain social relationships. Apart from that, many people use SNS to share private information like photos or videos or try to enlarge their circle of friends. Others just pursue the aim to collaborate or to have fun while playing online games and compete with friends ([24]; [51]; [62]; [65]; [67]; [72]). Additionally further SNS (such as Xing or LinkedIn) support the application process of job seekers by providing the possibility to upload CVs, connect with their job network or communicate with recruiters and headhunters for job offers [74]. In Germany the three most important reasons to participate in a SNS are to stay in contact with family and friends, to exchange information about common interests and to search for new friends [10]. Nonetheless, these potentials of SNS can only be realized if people participate within the same social network.

Although modern information technology offers various advantages and is used by many people - often daily ([43], [65], [72]) - the amount of people that are not willing to use and adopt to SNS is surprising ([41]; [57]; [58]; [75]). In Germany there are around 50 Million people who do not have a profile in a SNS. This accounts for almost two thirds of the people living in Germany ${ }^{1}$. Such a non-adoption behavior of IT in general has been recognized within IS research and potential reasons were raised and identified concerning different applications. Different reasons have been identified in previous research such as fear and threats as concern for privacy ([7]; [8]), psychological issues like resistance [49]; or simply social issues as age, education or income ([4]; [25]). In addition Peter Mertens analyzed why IT implementation projects fail [56].

Nonetheless, if people reject using new technologies or applications as social network platforms non-adoption will entail various problems. From a societal point of view the most important one is the advancing spread of society in a group of people adopting new technologies and one rejecting it. This phenomenon is actually discussed and known as Digital Divide or 
Digital Inequality [25]. It describes the amount of people, who have limited access to the internet or do not have the ability to use computers effectively and efficiently. Major reasons for the Digital Divide in Germany are the lacking availability of broadband internet access points [37] and especially demographic factors such as level of education, gender and age [46].

Concerning the factor age for use and acceptance of the internet there are distinct differences in the German population. More than 90 per cent of the young people between 14-and 29 years are internet users. In contrast, only 48.5 per cent of people between 60-69 years and just 19 per cent of the people 70+ years of age are internet users [1]. A large proportion of these people do not adopt the internet and its applications. Reasons for this non-adoption lie in the rapid development of the internet in the past 20 years and the related dissemination of information and communication technology. For example, people who retired around the millennium did mostly not come in contact with new media during their working career [73].

In order to counter the phenomenon of Digital Divide, the German Federal Government introduced several initiatives to reduce resistance and foster internet use of elderly people. SNS exist that target specifically the elderly population. In Germany feierabend.de is one example of a platform designed to support the social interaction of people aged 50 and older. This specific platform was awarded in 2008 as the "Best Community" in Germany by the German Federal Department of Economics and Technology as the platform supports especially the generation 50+ to find their way into and through the World Wide Web. The platform is designed to support the exchange of information and experiences as well as interactions of people with similar interests. For example feierabend.de established over 100 regional groups to enable meetings of their members within their city or region. These regional groups enabled feierabend.de to connect the online and offline lifes of elderly people. However, with only 600,000 visitors each month this particular SNS as well as other similar platforms only reach a small part of the potential user group of people at the age of 50 and older.

Based on the previous analysis, this paper focuses on people with at least 50 years of age and leaves out the "wired from birth" [12] generation. By using the Model of Adoption of Technology in Households (MATH; [70]; [13]) this paper will analyze factors leading to adoption or non-adoption behavior of SNS by elderly persons. This research is in line with Brown who argued that adoption research in the household context should focus on SNS [12] and with Pak et al. (2009) who identified age-sensitive design of online services as an important aspect of IS research [60].

Therefore this paper analyzes which factors of MATH have an influence on the decision to adopt a modern technology as SNS. Apart from that it is investigated, which MATH construct has the strongest predictive value and if there are differences for adopters and non-adopters in relation to the observed antecedents of the intention to use SNS.

For this purpose, this paper provides an overview of the research background and relevant literature in Section 2 dealing with the Digital Divide in general, SNS as well as IT adoption and nonadoption in the household context. Based on this, Section 3 contains the central hypotheses and explains the used research design. Section 4 comprises the research results which are then discussed in Section 5.

\section{Research Background}

Within in this section the Digital Divide in general, SNS and IT adoption and non-adoption in the household context are discussed in order to provide the relevant background information for the developed research model.

\subsection{IT Adoption and Non-Adoption in Households}

IT adoption in general is a highly studied research area within the IS discipline. According to Williams et al. [76], since 1985345 paper on technology adoption were published in the top 19 peerreviewed journals of the IS community. Nonetheless, most of these articles analyzed IT adoption in organizations. In principle, IT-adoption and non-adoption can be investigated within organizational [71] and private contexts ([13]; [12]). In order to analyze the private domain, Venkatesh and Brown processed the Model of Adoption of Technology in Households (MATH; [70]; [13]), which is based on the Theory of Planned Behavior [2] and explains the Behavioral Intention with the help of Attitudinal Beliefs, Normative Beliefs and Control Beliefs. Attitudinal Beliefs subsume Utilitarian Outcomes (degree of effectiveness and utility of using PC within households), Hedonic Outcomes (degree of pleasure or fun) and Social Outcomes (degree of status, power or knowledge resulting from PC household adoption). Normative Beliefs consider the impact of friends, family members and acquaintances and Control Beliefs regard possible inhibitors as cost, difficulty of use or Fear of Technology, which can end in rejecting a new technology. The resulting model was enlarged in 2005 as Brown and Venkatesh [13] identified Age, Income and Marital Status as moderator effects.

In terms of age Brown and Venkatesh showed that in general age is a moderator for Utilitarian, Hedonic and Social Outcomes as well as for Normative and Control Beliefs. The relationship between Utilitarian Outcomes and Behavioral Intention is moderated in such way that it is increasingly significant with age and even more for those who are married. The relationship between Hedonic Outcomes and Intention is moderated by age such that with increasing age Hedonic Outcomes are less important. In terms of Social Outcomes the impact of status gains on Intention to Use increase with age. Also Normative Beliefs are moderated by age such that friends and family as well as secondary sources are more important for elderly people. In terms of Control Beliefs (Fear of Technology and Perceived Behavioral Control or Perceived Ease of Use) a moderation effect by age were identified. Consequently, these antecedents are more important for older people.

Another distinguishing criterion within IT adoption research is the motivation why people use IT. Generally, people can use it because of a voluntary incentive or due to mandatory settings. Social network sites, which are the underlying technology within this paper, are a good research domain to analyze adoption behavior in households [12]. Within such a setting many people especially elderly people - reject using new technologies because they are not in a position to handle technologies and are not willing to ask for help if something did not work as planned [11]. This could be one reason, why the diffusion of broadband in 
households moves slower than expected ([22]; [26]). Based on this observation, Choudrie and Dwivedi [21] investigated the adoption of broadband in households with the help of MATH. According to Venkatesh and Brown [70] they identified several barriers as high costs, ease or difficulty of PC and internet use, lack of skill and lack of needs, which could result in a rejection of new technologies. For non-users only the lack of knowledge played a subordinated role in order to understand non-adoption behavior. On the other side, it was possible to show that each attitudinal factor was important to predict the usage behavior.

The complex theme "non-adoption" has not yet been researched as extensive as the actual adoption decision [47]. Nonetheless, several IS researchers started to investigate this behavior ([36]; [54]) and tried to motivate for further research endeavor. A recent publication within MISQ identified perceived values, switching costs or support as factors which can tip the balance and lead to non-adoption [45]. Such factors differ depending on the underlying context, so that other authors identified loss of status or power, uncertainty [40], pressure, exchange [29] or perceived threat ([7]; [9]) as significant influence factors which increase the probability to reject technologies. Eckhardt et al. [27] focused on the other side of social influence and investigated what groups exert an influence on the decision of people to refuse adopting a technology. A research model which explicitly should explain why people do not adopt social network platforms with the help of the Theory of Reasoned Action (TRA; [31]; [3]) was conducted by Laumer et al. [49]. In doing this, the authors disclosed negative significant correlations between an individual's personality trait resistance and each TRA construct.

\subsection{Social Network Sites}

Internet usage and cognition changed due to new opportunities within information and communication technologies. One of the most influential alteration emerged through Social Network Sites (SNS) as Facebook or the VZ-network (meinVZ, StudiVZ, SchülerVZ), which are famous SNS for German students and pupils.

Nowadays, about 11.44 per cent of the total population of the world is registered within Facebook [30]. Focusing more sophisticated countries as USA, Sweden, Canada or UK, this percentage rate rises up to 40 per cent. Such a high number of users could be explained by the variety of SNS possibilities. Each SNS user can communicate with friends or strangers, maintain relationships, enlarge their circle of friends, share private information, collaborate or just have fun ([24]; [51]; [62]; [65]; [67]; [72]). Due to this, many people integrated social network sites in their daily routine ([43], [65], [72]) and spend there between 10 minutes and 3 hours every day ([28]; [68]; [62]).

Contrary to internet flirtation pages, in which people search new friends and try to meet them afterwards in reality, social network sites are used in most instances to keep in touch with friends and acquaintances, which are known from the real offline world. Only afterwards, these known people will be added in the online friends list. This behavior is called Offline-to-Online phenomenon and is a distinctive characteristic of Facebook and comparable platforms ([28]; [51]; [55]; [44]; [65]).

Regarding different platforms Facebook with around 13 million users in January 2010 is the number one in Germany in terms of total users considering the VZ platforms as different ones. The VZ community has 14.4 million users in total. Also important are wer-kennt-wen.de, stayfriends.de and myspace.com. Feierabend.de has around 600.000 regular visitors as illustrated by Figure 1.

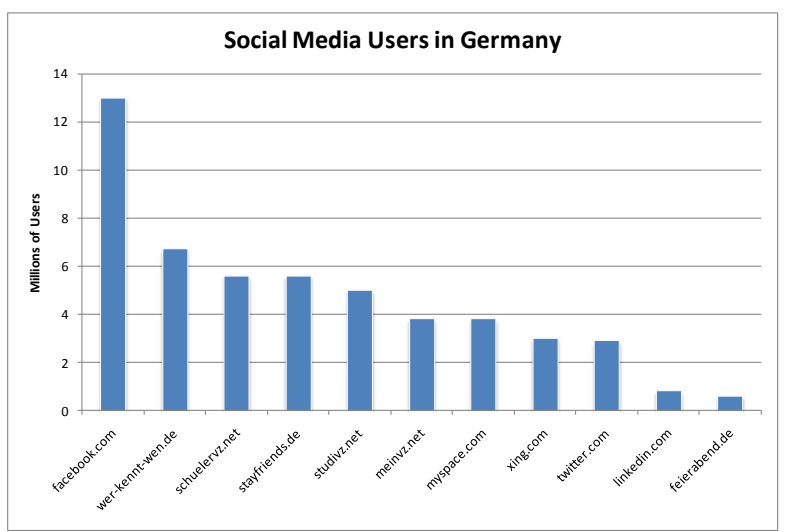

Figure 1: General SNS users in Germany [23]

In Germany, Facebook users are mainly students or young professionals between the age of 16 and 28 . On the other side, Figure 2 shows that with an increasing age, the user percentage decreases continuously. Consequently, only 5.12 per cent of all German Facebook users are at least 50 years old. Considering the whole German age distribution, which illustrates that the majority of people are older than 40 , it is obvious that the percentage rate for elderly Facebook users is very small.

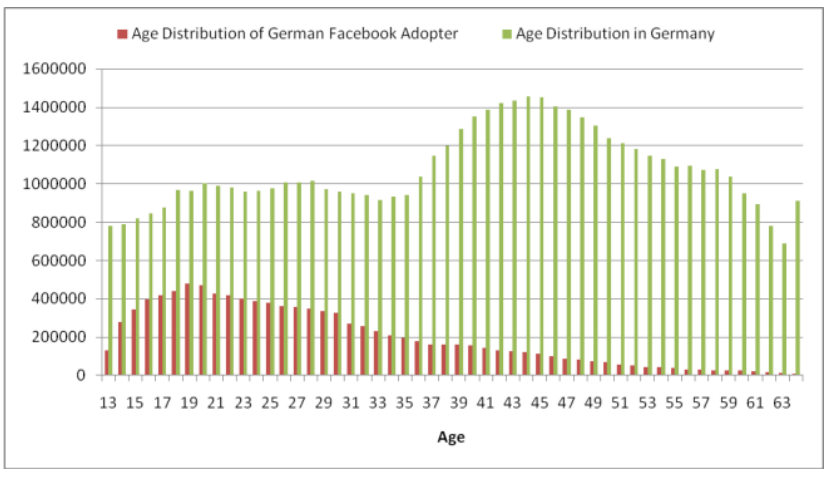

Figure 2: Age distribution of Facebook users

These figures indicates that SNS in general are mostly used by people younger than 30 and that platforms aimed at elderly are used only by a few people in relation to the posible number of users.

\subsection{Digital Divide}

Contrariwise to persons using SNS, people refusing such technologies, can get social problems through losing social contacts. This is one problematic consequence of the often discussed issue named Digital Divide.

The underlying question of the phenomenon Digital Divide is, whether people have access to internet or not. Afterwards, the scientific focus changed and age, income, rural residence, education, gender or race were studied together with their influence on non-usage of people. Along with it, researchers 
investigated not only non-adoption reasons but also differences in people's online skills and thus the ability to find effectively and efficiently information on the web [34]. The latter is often called Second-Level Digital Divide or Digital Inequality and distinguishes self from Digital Divide by focusing not only on the question whether people have access to internet or not. Moreover it focuses on skills and knowledge of people using several technologies such as computers, internet or SNS [69].

Lots of problems, which were discussed through the rise of ICT, as privacy issues, interface issues, a lack of incentives or too complex technologies for most of the households (e.g. [69]) bias elderly in a more serious manner than younger persons. It is not self-evident that each person had contact with modern ICT within their workplace or has friends, acquaintances or family members who can explain them how to handle each new application. Another important facet for elderly persons is their preference to sustain their habitual daily routine and their reluctance to change their way of life. If people had no contact with ICT like computers or social network sites, such a technology or application can change one's life in dramatically way. Because of this, especially the elderly people try to maintain their status quo [45] and burke new innovations. In this context, the extent of an inherit attitude towards changing the status quo has to be regarded as well ([8]; [7]; [49]; [59]).

To overcome this problem in Germany, the Federal Government identified this issue and started initiatives to introduce elderly or inexperienced people to internet possibilities. Next to this, the program of the Federal Government also focuses on population groups with different backgrounds, women in rural areas or internet-interested people and thus takes account of the phenomenon Digital Inequality. Apart from the Federal Government, many other initiatives try to give elderly or unprivileged people an understanding of new and modern ICT. For example, the social network site Feierabend.de tries to address exactly this group of elderly people (50 years or older) and provides them a platform to stay in contact with friends, to enlarge their circle of friends or just to discuss topics which are important and interesting for elderly persons as acoustic hearing apparatus. Apart from that, this SNS throws light on privacy problems and alerts for tricksters and other potential traps.

Based on this general research background of digital inequality and SNS as well as the theoretical background of IT adoption in households the following sections describes the used research model and design to investigate adoption of SNS by elderly people.

\section{Research Model and Design}

Within this section, our research model will be developed. Based on the Model of Adoption of Technology in Households (MATH) ([13]; [70]), the influence of different constructs will be analyzed for adopters and non-adopters of SNS. Finally, the used data sample is provided and the research design will be explained.

\subsection{Research Model}

The general theoretical foundation for the presented research model is the MATH, which investigates the influence of Attitudinal, Control and Normative Beliefs on Behavioral Intention. With the help of this model, both adopters and nonadopters behavioral intention will be analyzed separately.
For both groups, the six hypotheses as arranged by Brown and Venkatesh ([13]; [70]) will be adapted and analyzed for elderly people. Thereby, the hypotheses are:

H1: Utilitarian Outcomes (Attitudinal Beliefs) has a direct positive influence on Intention of elderly people.

H2: Hedonic Outcomes (Attitudinal Beliefs) has a direct positive influence on Intention of elderly people.

H3: Social Outcomes (Attitudinal Beliefs) has a direct positive influence on Intention of elderly people.

H4: Subjective Norm (Normative Belief) has a direct positive influence on Intention of elderly people.

H5: Perceived Ease of Use (Control Beliefs) has a direct positive influence on Intention of elderly people.

H6: Fear of Technology (Control Beliefs) has a direct negative influence on Intention of elderly people.

The research model is illustrated by Figure 3 .

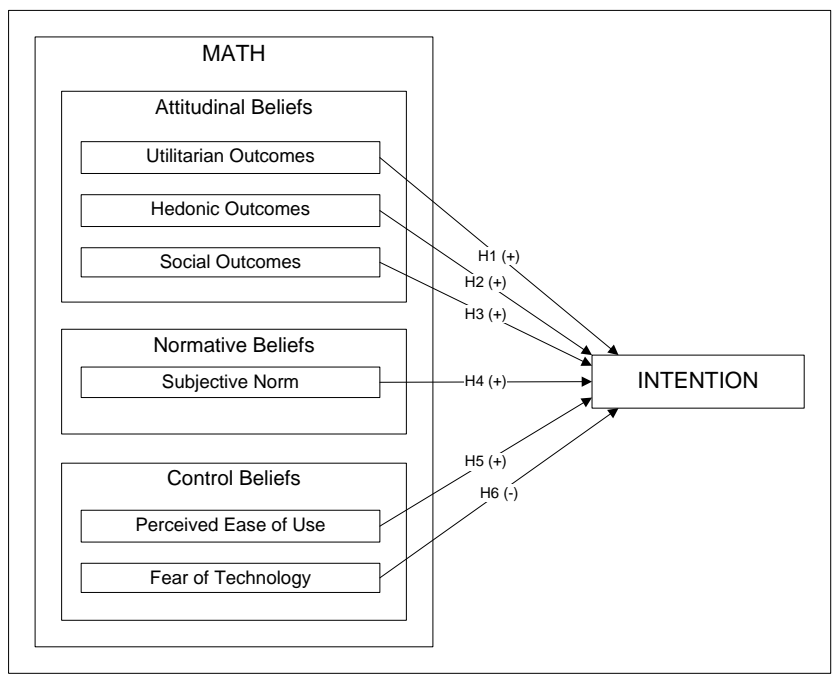

Figure 3: Research Model

\subsection{Research Design and Participants}

For the evaluation of the research model data of SNS (non)adoption was collected within a general study of IT usage. The aim of this study was to explain why people do (not) use particular online services even if they have access to the internet. Therefore an online survey was conducted to collect empirical data. In order to reach people who are used to the internet in general and with different social background, demographics and knowledge background, this method seemed to be the most appropriate. Using this methodology and focusing on SNS as well as on elderly people within the study who are used to the internet and have a profile in an SNS or not could be researched. 
Based on this data, SPSS Statistics 17.0 and Smart PLS ([63]) were utilized to analyze the influence of the six MATH constructs on intention to use SNS. The evaluation did not include incomplete data samples. As the focus within this paper is to analyze the adoption and non-adoption behavior of elderly people data of 53 SNS non-adopters and 115 SNS adopters, older than 50 years, is the underlying for this research endeavor.

The demographic information, separated by the actual adoption behavior could be seen in Table 1. In both groups are more men than women additionally more participants are between 50 and 54 years old as people older than 55. Nonetheless, the annual income and the whole demographics of both groups are comparable

Table 1: Research participants

\begin{tabular}{|c|c||c|c|}
\hline \multicolumn{2}{|c|}{ Demographics of ... } & 115 Adopters & 53 Non-Adopters \\
\hline \hline \multirow{3}{*}{ Gender } & Men & $72.2 \%$ & $75.5 \%$ \\
\cline { 2 - 4 } & Women & $27.8 \%$ & $24.5 \%$ \\
\hline \multirow{4}{*}{ Age } & $50-54$ & $55.5 \%$ & $54.5 \%$ \\
\cline { 2 - 4 } & $55-59$ & $32.3 \%$ & $34.0 \%$ \\
\cline { 2 - 4 } & $60-64$ & $12.2 \%$ & $11.5 \%$ \\
\hline \multirow{5}{*}{ Annual Income } & $<20 \mathrm{~K}$ & $25.2 \%$ & $34.0 \%$ \\
\cline { 2 - 4 } & $20-25 \mathrm{~K}$ & $7.8 \%$ & $11.3 \%$ \\
\cline { 2 - 4 } & $25-35 \mathrm{~K}$ & $16.5 \%$ & $11.3 \%$ \\
\cline { 2 - 4 } & $35-45 \mathrm{~K}$ & $16.5 \%$ & $11.3 \%$ \\
\cline { 2 - 4 } & $45-55 \mathrm{~K}$ & $7.8 \%$ & $9.4 \%$ \\
\cline { 2 - 4 } & $55-65 \mathrm{~K}$ & $7.0 \%$ & $3.8 \%$ \\
\cline { 2 - 4 } & $65-80 \mathrm{~K}$ & $4.4 \%$ & $5.7 \%$ \\
\cline { 2 - 4 } & $>=80 \mathrm{~K}$ & $14.8 \%$ & $13.2 \%$ \\
\hline
\end{tabular}

\section{Research Results}

This section validates the research model for SNS adopters and non-adopters. Therefore, a measurement model and a structural model will be provided within the following two sections as we transferred our research model into a structural equation model and used Partial Least Squares for data analysis.

\subsection{Measurement Model}

Each of the seven constructs used - Social Outcomes, Hedonic Outcomes, Utilitarian Outcomes, Subjective Norm, Perceived Ease of Use, Fear of Technology and Intention - are measured with reflective indicators as in previous publications. Consequently, content validity, indicator reliability, construct reliability and discriminant validity have to be validated for each construct [5].

\subsubsection{Content validity}

While setting up the questionnaire, the aim was to refer to questions within the questionnaire, which were already used in empirical research by other researchers. However, following a recent discussion in IS research about the use of Fast Forms for empirical data collection [19] the item identified in prior research were converted to fast forms using semantic differentials and some of these questions had to be modified in order to fit the SNS context. The items used are illustrated at Table 2. These items have been pretested within the general study of IT usage.
Table 2: Measurement items

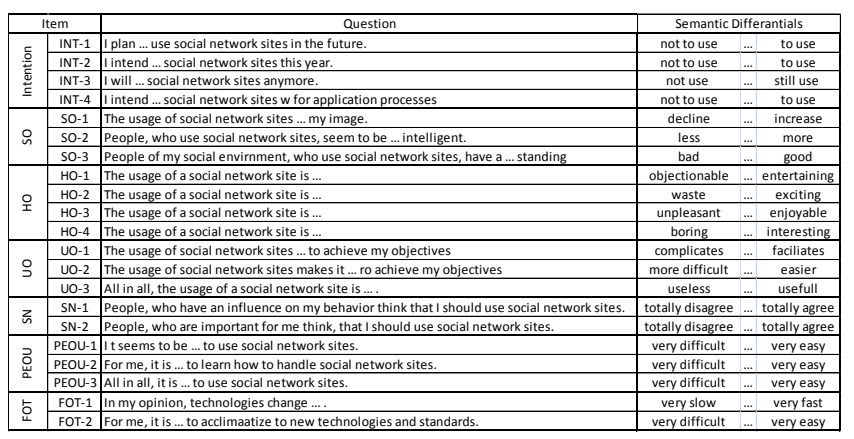

\subsubsection{Indicator reliability}

The proportion of the variance of an indicator, which derives from the relevant latent variables, will be shown by the indicator reliability. Each item should have at least a greater loading than 0.4 , so that item SO-2 has to be removed within the non-adopter case [38]. For the rest, each value is greater than 0.7 , whereby 50 per cent of the variance of a latent variable is explained by the used indicators [15]. All loadings have a significance level of $p<$ 0.001 and are highly significant. This was calculated by using a bootstrap method with 5000 samples [35].

Table 3: Indicator reliability, construct reliability and discriminant validity for adopter

\begin{tabular}{|c|c|c|c|c|c|c|c|c|c|c|c|c|}
\hline & Item & Loading & Mean & AVE & CR & \multicolumn{7}{|c|}{ Latent Variable Correlation } \\
\hline \multirow{4}{*}{ 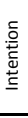 } & INT-1 & 0.971 & \multirow[b]{4}{*}{3.316} & \multirow[b]{4}{*}{0,8666} & \multirow[b]{4}{*}{0.9628} & \multirow[b]{4}{*}{0,93091} & & & & & & \\
\hline & INT-2 & 0.934 & & & & & & & & & & \\
\hline & INT-3 & 0.970 & & & & & & & & & & \\
\hline & INT-4 & 0.843 & & & & & & & & & & \\
\hline \multirow{3}{*}{ 요 } & So-1 & 0.878 & & & & \multirow[b]{3}{*}{0,87436} & \multirow[b]{3}{*}{0.5225} & & & & & \\
\hline & So-2 & 0.901 & & & & & & & & & & \\
\hline & so-3 & 0.844 & 3.152 & 0,7645 & 0.9068 & & & & & & & \\
\hline \multirow{4}{*}{ 오 } & HO-1 & 0.828 & & & & & & & & & & \\
\hline & HO-2 & 0.810 & & & & & & & & & & \\
\hline & $\mathrm{HO}-3$ & 0.981 & & & & & & & & & & \\
\hline & $\mathrm{HO}-4$ & 0.908 & 4.308 & 0,7587 & 0.9261 & 0,87103 & 0.5549 & 0.5711 & & & & \\
\hline \multirow{3}{*}{ ㅇ } & UO-1 & 0.896 & & & & & & & & & & \\
\hline & UO-2 & 0.893 & & & & & & & & & & \\
\hline & Uo-3 & 0.939 & 3.243 & 0,8268 & 0.9347 & 0,90929 & 0.6437 & 0.5892 & 0.6637 & & & \\
\hline \multirow{2}{*}{ in } & SN-1 & 0.975 & & & & & & & & & & \\
\hline & $\mathrm{SN}-2$ & 0.973 & 3.720 & 0,9485 & 0.9736 & 0,97391 & 0.5847 & 0.4234 & 0.5257 & 0.5753 & & \\
\hline \multirow{3}{*}{ 己ِّ } & PEOU-1 & 0.956 & & & & & & & & & & \\
\hline & PEOU-2 & 0.945 & & & & & & & & & & \\
\hline & PEOU-3 & 0.955 & 3.488 & 0,9061 & 0.9666 & 0,95189 & 0.4627 & 0.4953 & 0.5531 & 0.4455 & 0.4142 & \\
\hline \multirow{2}{*}{ เo } & FOT-1 & 0.887 & & & & & & & & & & \\
\hline & FOT-2 & 0.845 & 3.605 & 0,7499 & 0.8570 & 0,86597 & $-0,0605$ & $-0,1048$ & 0.1563 & 0.078 & $-0,0046$ & 0.2040 \\
\hline \multicolumn{13}{|c|}{ Note: All loadings are significant at $p<0.001$; Square Root of AVE is listed on diagonal by LVC } \\
\hline & & & & & & Adopte & & & & & & \\
\hline
\end{tabular}

\subsubsection{Construct reliability}

Composite Reliability (CR) and Average Variance Extracted (AVE) were used to assess the quality at the construct level [32]. Therefore, each CR value should be over 0.7 and AVE should be higher than 0.5 [6]. Both conditions are fulfilled for users and non-users as illustrated in Table 3 and Table 4

\subsubsection{Discriminant validity}

Discriminant validity describes the extent, to which measurement items differ from others which theoretically should not be equal [14]. In order to show this, the construct correlations should be 
smaller than the root of the corresponding AVE ([38]; [32]). As Table 3 and Table 4 show, this criterion is fulfilled by the data collected for this study.

Table 4: Indicator reliability, construct reliability and discriminant validity for non-adopter

\begin{tabular}{|c|c|c|c|c|c|c|c|c|c|c|c|c|}
\hline \multicolumn{2}{|r|}{ Item } & \multirow{2}{*}{\begin{tabular}{|l|} 
Loading \\
0.956 \\
\end{tabular}} & \multirow{2}{*}{ Mean } & \multirow{2}{*}{ AVE } & \multirow[t]{2}{*}{$C R$} & \multicolumn{7}{|c|}{ Latent Variable Correlation } \\
\hline \multirow{4}{*}{ 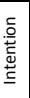 } & INT-1 & & & & & \multirow[b]{4}{*}{0,93856} & & & & & & \\
\hline & INT-2 & 0.958 & \multirow[b]{3}{*}{2.176} & \multirow[b]{3}{*}{0,8809} & \multirow[b]{3}{*}{0,9673} & & & & & & & \\
\hline & INT-3 & 0.944 & & & & & & & & & & \\
\hline & INT-4 & 0.895 & & & & & & & & & & \\
\hline \multirow{3}{*}{ 오 } & so-1 & 0.808 & \multirow[b]{3}{*}{2.984} & \multirow[b]{3}{*}{0,7079} & \multirow[b]{3}{*}{0,8288} & \multirow[b]{3}{*}{0,84137} & \multirow[b]{3}{*}{0.4551} & & & & & \\
\hline & $50-2$ & & & & & & & & & & & \\
\hline & so-3 & 0.874 & & & & & & & & & & \\
\hline \multirow{4}{*}{ 오 } & HO-1 & 0.802 & & & & & & \multirow[b]{4}{*}{0.5848} & & & & \\
\hline & $\mathrm{HO}-2$ & 0.952 & \multirow[b]{3}{*}{3.651} & \multirow[b]{3}{*}{0,7748} & \multirow[b]{3}{*}{0,9319} & \multirow[b]{3}{*}{0,88023} & \multirow[b]{3}{*}{0.2223} & & & & & \\
\hline & $\mathrm{HO}-3$ & 0.823 & & & & & & & & & & \\
\hline & HO-4 & 0.934 & & & & & & & & & & \\
\hline \multirow{3}{*}{$\stackrel{\circ}{\rightrightarrows}$} & UO-1 & 0.907 & \multirow[b]{3}{*}{2.591} & \multirow[b]{3}{*}{0,8626} & \multirow[b]{3}{*}{0,9496} & \multirow[b]{3}{*}{0,92876} & \multirow[b]{3}{*}{0.5380} & & & & & \\
\hline & UO-2 & 0.937 & & & & & & & & & & \\
\hline & UO-3 & 0.942 & & & & & & 0.7681 & 0.6659 & & & \\
\hline$z$ & SN-1 & 0.975 & & & & & & & & & & \\
\hline$n$ & $\mathrm{SN}-2$ & 0.957 & 2.818 & 0,9327 & 0,9652 & 0,96576 & 0.2977 & 0.4949 & 0.6786 & 0.5871 & & \\
\hline & PEOU-1 & 0.946 & & & & & & & & & & \\
\hline 足 & PEOU-2 & 0.952 & & & & & & & & & & \\
\hline & PEOU-3 & 0.977 & 2.737 & 0,9182 & 0.9712 & 0,95823 & 0.1994 & 0.6105 & 0.3312 & 0.5257 & 0.1884 & \\
\hline 5 & FOT-1 & 0.752 & & & & & & & & & & \\
\hline 4 & FOT-2 & 0.927 & 3.433 & 0,7123 & 0.0500 & 0,84398 & $-0,425$ & $-0,2267$ & $-0,217$ & $-0,347$ & $-0,4069$ & 0.0759 \\
\hline & Note: & All loadin & gs are s & ignifican & it at $p<0$. & .001 ; Squa & re Rooto & f AVE is li & isted on & idiagona & 1 by LVC & \\
\hline & & & & & & Non-Add & & & & & & \\
\hline
\end{tabular}

As a consequence, it is possible to conclude that the measurement model has a high validity.

\subsection{Structural model}

After validating the measurement model, the structural model will be evaluated. In order to do this, the coefficient of determination $\left(\mathrm{R}^{2}\right)$ and the significance levels of the path coefficients [17] need to be observed.

Figure 4 shows that in the adopter case, 52.9 per cent of the variance of Intention can be explained by the six used constructs. Within the non-adopter case, 40.3 per cent of the variance is clarified. According to Chin [17] both models provide an acceptable goodness of fit. For non-adopters, two significant relationships can be confirmed. The first one is the negative influence of Fear of Technology on Intention and a positive impact of Utilitarian Outcomes on the dependent variable.

On the other side, these two relationships were also significant for the group of adopters. Apart from this, two more impacts were identified. These are the influence of Subjective Norm and Perceived Ease of Use on Intention. Only Social and Hedonic Outcomes seem to have no effect on Intention for both elderly adopters and non-adopters of SNS.

\subsection{Group Comparison}

Next to the previous results like the correlation between intention and each construct,

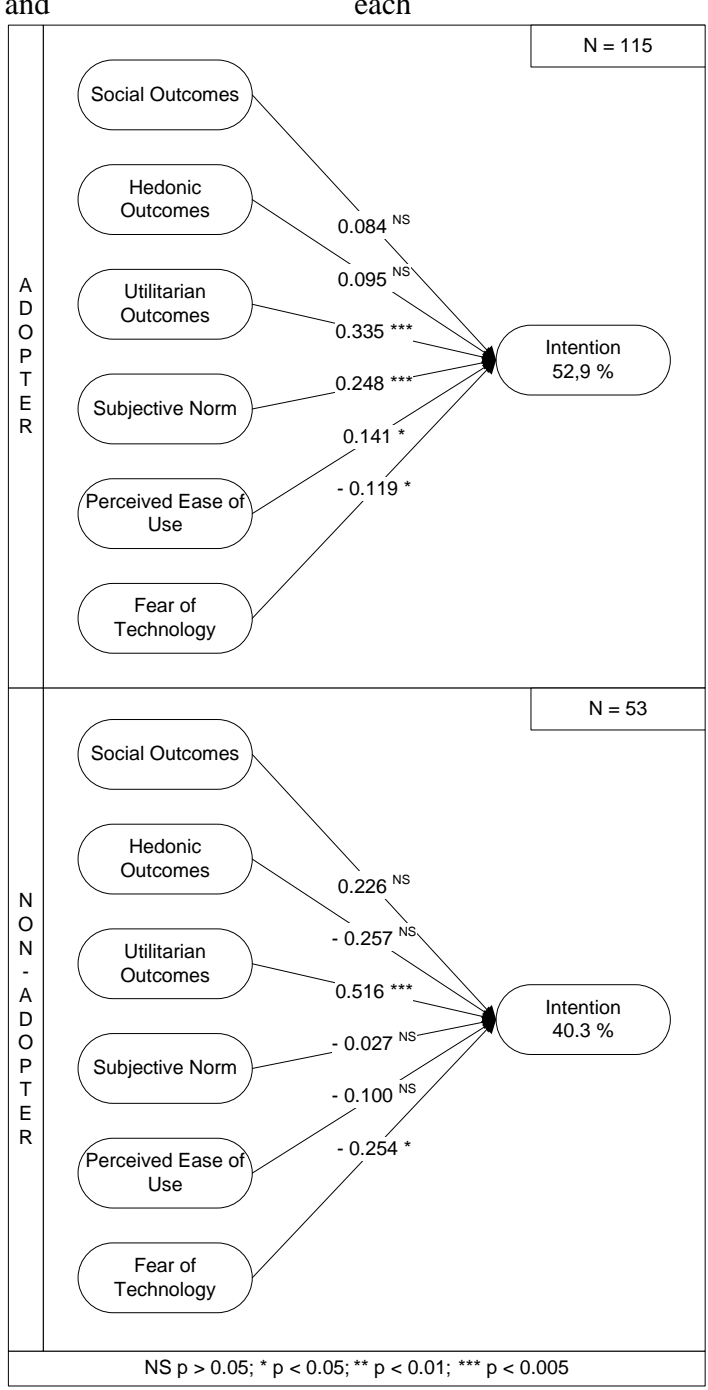

Figure 4: Structural Model

Table 5 represents the strength of effect for each construct and both groups. For adopters and non-adopters, the construct Utilitarian Outcomes has the highest impact on intention. Apart from that Fear of Technology plays an important role for nonadopters, whereas for adopters, this aspect is only of little importance.

Whether comparisons of means are investigated, only the aspect Social Outcomes is not significantly different for both adopter groups. The responsiveness of all other constructs is significantly different. 


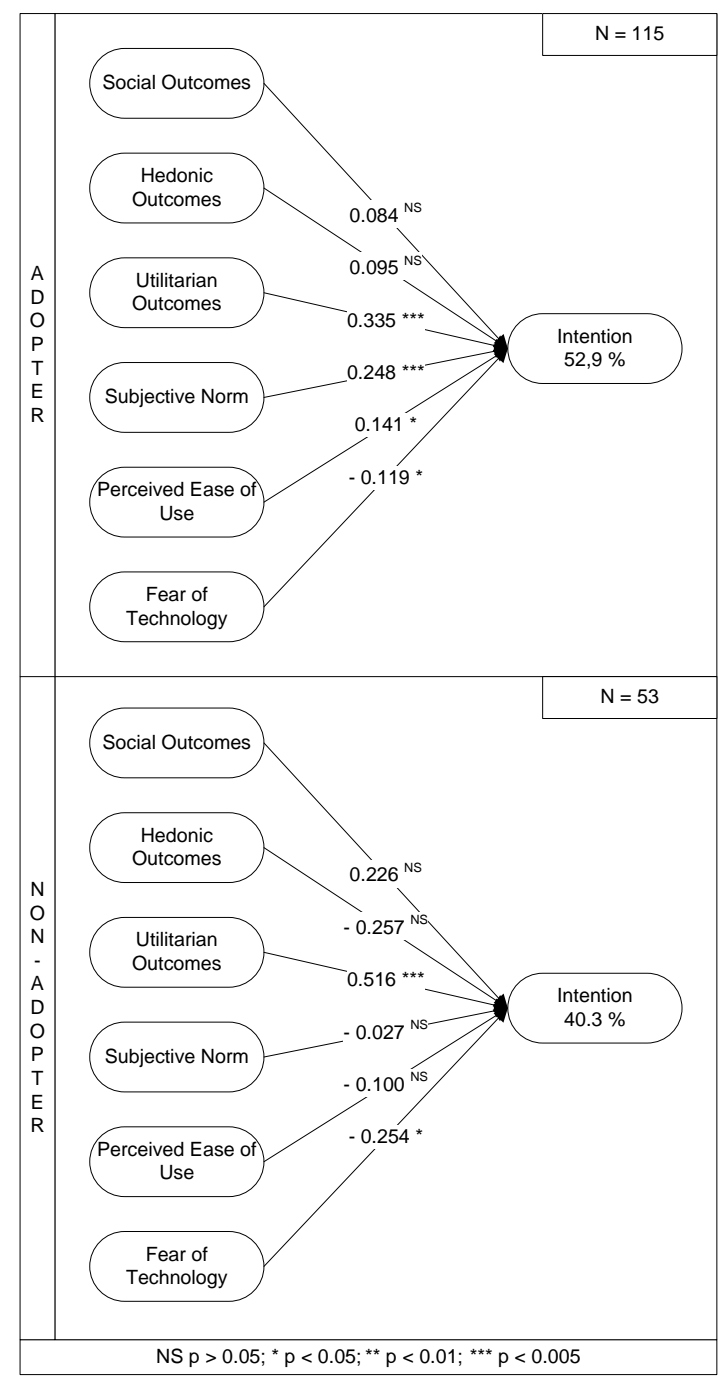

Figure 4: Structural Model

Table 5: Strength of Effect \& Comparison of means

\begin{tabular}{|c|c|c|c|c|c|c|c|}
\hline \multirow[b]{2}{*}{ Inputfactor } & \multirow[b]{2}{*}{ Group } & \multirow[b]{2}{*}{$\begin{array}{l}\text { Correlation with } \\
\text { Intention }\end{array}$} & \multirow[b]{2}{*}{$\begin{array}{c}\text { Strength of } \\
\text { Effect }\end{array}$} & \multirow[b]{2}{*}{ Mean } & \multicolumn{3}{|c|}{ Comparison of means } \\
\hline & & & & & $\begin{array}{l}\text { Levene-Test \& } \\
\text { Homogeneity } \\
\text { of Variance }\end{array}$ & T & Sig. \\
\hline \multirow{2}{*}{ Intention } & \begin{tabular}{|l|} 
Adopter \\
\end{tabular} & - & - & 3.316 & \multirow{2}{*}{ Yes $(0.520)$} & \multirow{2}{*}{5.635} & \multirow{2}{*}{0.000} \\
\hline & Non-Adopter & - & - & 2.176 & & & \\
\hline \multirow{2}{*}{ Social Outcomes } & \begin{tabular}{|l|} 
Adopter \\
\end{tabular} & Not significant & $1.6 \%$ & 3.152 & \multirow{2}{*}{ Yes $(0.124)$} & \multirow{2}{*}{1.529} & \multirow{2}{*}{0.133} \\
\hline & \begin{tabular}{|l|} 
Non-Adopter \\
\end{tabular} & Not significant & $2.9 \%$ & 2.984 & & & \\
\hline \multirow{2}{*}{ Hedonic Outcomes } & \begin{tabular}{|l|} 
Adopter \\
\end{tabular} & Not significant & $1.6 \%$ & 4.308 & \multirow{2}{*}{ Yes (0.322) } & \multirow[t]{2}{*}{2.561} & \multirow[t]{2}{*}{0.013} \\
\hline & \begin{tabular}{|l|} 
Non-Adopter \\
\end{tabular} & Not significant & $2.7 \%$ & 3.651 & & & \\
\hline \multirow{2}{*}{ Utilitarian Outcomes } & Adopter & Significant & $14.1 \%$ & 3.243 & \multirow{2}{*}{ Yes $(0.532)$} & \multirow{2}{*}{3.622} & \multirow{2}{*}{0.001} \\
\hline & \begin{tabular}{|l|} 
Non-Adopter \\
\end{tabular} & Significant & $13.1 \%$ & 2.591 & & & \\
\hline \multirow{2}{*}{ Subjective Norm } & \begin{tabular}{|l|} 
Adopter \\
\end{tabular} & Significant & $7.9 \%$ & 3.720 & \multirow{2}{*}{ Yes (0.302) } & \multirow{2}{*}{2.683} & \multirow{2}{*}{0.010} \\
\hline & \begin{tabular}{|l|} 
Non-Adopter \\
\end{tabular} & Not significant & $0.0 \%$ & 2.818 & & & \\
\hline \multirow{2}{*}{ Perceived Ease of Use } & \begin{tabular}{|l|} 
Adopter \\
\end{tabular} & Significant & $0.4 \%$ & 3.488 & \multirow{2}{*}{ Yes $(0.420)$} & \multirow{2}{*}{3.596} & \multirow{2}{*}{0.001} \\
\hline & \begin{tabular}{|l|} 
Non-Adopter \\
\end{tabular} & Not significant & $3.1 \%$ & 2.737 & & & \\
\hline \multirow{2}{*}{ Fear of Technology } & \begin{tabular}{|l|} 
Adopter \\
\end{tabular} & Significant & $2.3 \%$ & 3.605 & \multirow{2}{*}{ Yes $(0.150)$} & \multirow[t]{2}{*}{2.064} & \multirow{2}{*}{0.042} \\
\hline & Non-Adopter & Significant & $11.4 \%$ & 3.433 & & & \\
\hline
\end{tabular}

Finally, the significance of the path coefficients was compared for adopters and non-adopters using the proposed procedure by Chin and Dibbern [18]. While doing so, it can be identified, that all paths are highly different for both adopters and non-adopters. In particular for non-adopters Fear of Technology has an higher mean value for non-adopters and the mean of the generated bootstrapped samples is significant different from adopters. Moreover for Utilitarian Outcomes the mean value is higher for non-adopters and significant different from adopters. For adopters, Subjective Norm and Perceived Ease of Use has a higher mean for adopters and is significant different from nonadopters. In terms of the two insignificant paths in both samples Social Outcomes has a higher mean for non-adopters and Hedonic Outcomes for adopters. Both are significant different between the two groups tested. The comparison of path coefficient is illustrated by Table 6 .

Table 6: Comparison of Path Coefficient

\begin{tabular}{|c|c|c|c|c|c|c|}
\hline \multirow[b]{2}{*}{ Path } & \multirow[b]{2}{*}{ Group } & \multirow[b]{2}{*}{ Mean Value } & \multirow[b]{2}{*}{$\begin{array}{c}\text { Standard } \\
\text { Deviation }\end{array}$} & \multicolumn{3}{|c|}{ Comparison of Path Coefficient } \\
\hline & & & & $\begin{array}{l}\text { Levene- } \\
\text { Test }\end{array}$ & T & Sig. \\
\hline \multirow{2}{*}{ SO -->INT } & Adopter & 0.103 & 0.068 & \multirow{2}{*}{ No $(0.000)$} & \multirow{2}{*}{17.088} & \multirow{2}{*}{0.000} \\
\hline & Non-Adopter & 0.223 & 0.142 & & & \\
\hline \multirow{2}{*}{ HO -->INT } & Adopter & 0.112 & 0.078 & \multirow{2}{*}{ No $(0.000)$} & \multirow{2}{*}{-43.454} & \multirow{2}{*}{0.000} \\
\hline & Non-Adopter & -0.281 & 0.182 & & & \\
\hline \multirow{2}{*}{ UO --> INT } & Adopter & 0.349 & 0.098 & \multirow{2}{*}{ No $(0.000)$} & \multirow{2}{*}{17.866} & \multirow{2}{*}{0.000} \\
\hline & Non-Adopter & 0.534 & 0.210 & & & \\
\hline \multirow{2}{*}{ SN -->INT } & \begin{tabular}{|l|} 
Adopter \\
\end{tabular} & 0.244 & 0.090 & \multirow{2}{*}{ No $(0.000)$} & \multirow{2}{*}{-57.252} & \multirow{2}{*}{0.000} \\
\hline & Non-Adopter & -0.164 & 0.131 & & & \\
\hline \multirow{2}{*}{ PEOU -->INT } & Adopter & 0.148 & 0.079 & \multirow{2}{*}{ No $(0.000)$} & \multirow{2}{*}{-48.119} & \multirow{2}{*}{0.000} \\
\hline & Non-Adopter & -0.130 & 0.102 & & & \\
\hline \multirow{2}{*}{ FOT -->INT } & Adopter & -0.118 & 0.065 & \multirow{2}{*}{ No $(0.000)$} & \multirow{2}{*}{-27.812} & \multirow{2}{*}{0.000} \\
\hline & Non-Adopter & -0.280 & 0.079 & & & \\
\hline
\end{tabular}

\subsection{Limitations}

This paper is a first try to analyze the intention of adopters and separately - non-adopters within the MATH for elderly persons. Consequently, the results cannot be generalized limitless. First of all, the presented results derive from one online survey, so that only persons with internet access could participate. It is conceivable that the elderly people without internet access cannot participate and might show other reasons and therefore other correlations which lead to a non-adoption of SNS. On the other hand, it was important to ensure that each SNS non-adopter knows SNS and the involved advantages and disadvantages. This issue was addressed with different questions such as "I know the possibility to engage in social network sites like Facebook", "Advantages of social network sites are (participants could chose between different items or 'I don't know')" or "The first time I heard about social network sites was in (date)". Consequently, each non-adopter analyzed within this paper knows about SNS but does not use it. By collecting data in another way, it could be more problematic to separate between adopters, non-adopters and non-adopters which do not know about the existence of SNS.

Another crucial aspect within this publication is that only one technology was analyzed. Although Brown [12] advised using SNS when household adaption should be investigated, the model has to be confirmed by other researchers observing other technologies. The same will be true for the underlying culture. Dependent on the cultural background, the model could offer different correlations [33].

The last restriction is the relative small number of SNS nonadopters $(\mathrm{N}=53)$ which participated. Considering, that the impact of six constructs on Intention was investigated, 60 data samples should have been the underlying basis [20]. By increasing the data sample up to the crucial threshold (by adding non-users which do not know SNS or by not eliminating incomplete samples), the results were still the same. 


\section{Discussion and Future Research}

In general the findings of this paper show, that elderly people's adoption of SNS is determined by other perceptions and constructs than their non-adoption of SNS. For adopters a significant impact of Normative Beliefs measured as Subjective Norm, Perceived Ease of Use as a part of Control Beliefs on Intention to use SNS could be observed. Contrary, for nonadopters these perceptions have no significant influence on their intention. Nonetheless, these results do not implicate that nonadopters regard new IS as simple to use. By regarding the comparison of means, non-adopters consider the handling of SNS more cumbersome to use than people adopting SNS. The same could be monitored for Subjective Norm. Elderly non-adopters sense that the perceived pressure to adopt social network sites applied by their circle of friends and acquaintances is less than by the social environment of adopters. Future research could consider whether elderly SNS non-adopters have a smaller circle of friends or analyze whether their friends are also SNS nonadopters. Taking into account the Utilitarian Outcomes, which is the most important factor influencing the Intention, reveal that elderly non-adopters face SNS and their possibilities as less useful than elderly adopters.

Most of the people using such modern ways to communicate just use it to stay in contact with friends, they know from the real offline world, and do not try to enlarge their circle of friends by finding new contacts with equal interests. This phenomenon is called Offline-to-Online paradigm [65] and reveals that SNS users first know people from school, job, leisure activities or other activities based in the offline world and afterwards add these people in online communities to their friend lists. As the example of feierabend.de illustrates, SNS for elderly people are designed to enable social exchange between their users in both cases, known form the offline world or not. Therefore another opportunity for future research is to analyze whether the discussed offline-toonline paradigm also holds for elderly people.

Moreover other research activities identified enjoyment as the major predictor for using social networks whereas Usefulness is just less relevant [64]. The findings of this research cannot confirm this totally for elderly people. Our research indicates that people, which are older than 50 years, emphasize utilitarian facets of social networks and regard hedonic outcomes as less relevant. Nonetheless, elderly SNS adopters report having significantly more fun in using SNS than non-adopters, but in both cases, no significant influence on the usage decision could be observed. This could be explained by Phang et al. [61] who investigated the individual behavior in online communities depending on the distinct usage causes. They differentiated between knowledge seeking and knowledge contribution and support that usefulness is essential for people searching knowledge. Since, it is likelier that younger persons use the internet and social network sites to play games or funny quizzes, elderly people will utilize platforms as Facebook or feierabend.de as a source of information (for example about friends or acquaintances) whereby the usefulness is a more crucial issue.

Another important difference between adopters and non-adopters of SNS is the perceived Fear of Technology. In both cases, an influence on Intention could be monitored as well as significant unequal means. Thereby especially non-adopters have problems to engage with new technologies as computers, internet or social networks. For this reason, Fear of Technology has a strong impact on the decision for non-adopters. For these anxiously elderly people, new initiatives should be initiated to make SNS and other technologies accessible to them. The Digital Divide can be addressed, if these persons could be prepared for using new technologies. Nonetheless, this is not only a challenge for the Federal Government, to ensure that people can use modern ICT at home, it is also essential to handle these technologies within organizational contexts. If this group of people, who reject to adopt new technologies, is not able to deal with them or if they fear them, they will hinder the operating schedule. This is clearly reflected by Luftman and Kempaiah [53], which ranked the management of change as the sixth most critical issue for Chief Information Officers. This also comprises IS modifications, but these can only be successful if employees are able to engage in new situations [49] and are not afraid of IS. The latter could diminished by offering regular IS courses and IT trainings by the organization and thus, organizations could create competitive advantages. Feierabend.de has implemented an extended support for elderly people (e.g. offering services to scan pictures, hotline activities, extended explanation of services, etc.) Summing up, it is essential to give people an understanding of IT and IS because of both, to maintain a balanced economy - or sustainability at the corporate level - and from a sociological point of view to reduce the Digital Divide and Digital Inequality.

In general regarding the MATH the results of this research have some implications for the understanding of technology adoption in a private environment. By focusing on people older than 50 and by distinguishing between adopters and non-adopters the results indicate that within the group of people older than 50 the importance of each factor within the MATH is different for adopters and non-adopters. Elderly adopters are mainly driven by Utilitarian Outcomes, Subjective Norm, Perceived Ease of Use and Fear of Technology. In contrast elderly non-adopters are mainly influenced by Utilitarian Outcomes, and Fear of Technology. Moreover regarding significant difference in the mean of each construct the results indicate that Social Outcomes, Hedonic Outcomes, Utilitarian Outcomes, Subjective Norm and Perceived Ease of Use have a higher acceptance by adopters than by non-adopters. In contrast non-adopters are more afraid in terms of Fear of Technology. In addition, regarding the strength of effect the results show that for adopters and non-adopters the strongest effect can be observed for Utilitarian Outcomes as well as for Fear of Technology. In general these results point out that the relevance of each antecedent is different for adopters and nonadopters.

Apart from that by considering the $\mathrm{R}^{2}$ of both adopters and nonadopters it is obviously that the explanation power is higher for adopters than for non-adopters. Consequently it would be quite conceivable to develop a model which explains - in particular the non-adoption behavior. Therefore, first attempts which discussed such an approach could be found in the literature [48]. Nonetheless, it would be necessary to identify different reasons leading to non-adoption, as a status quo bias [42], resistance ([49]; [7]; [8]) or other inhibitors [16] as fear or threats.

Nonetheless this research shows that the MATH model is also valid for elderly people. Although, lots of future research will be necessary to understand the behavior of the elderly people altogether. This research was just a first attempt to enlighten 
factors influencing adoption and non-adoption of the elderly people.

In terms of the methodology used it could be evaluated that the proposed Fast Form approach [19] is applicable to the MATH and empirical studies using MATH as all items are statistically useable for the model evaluation.

By analyzing the domain social network sites it is interesting that Hedonic Outcomes as fun provided by the platform have no impact on the intention. Given that fun is no significant impact factor for elderly people it is probable that these people for example do not play online social games in SNS. Thereby researchers could analyze which SNS services and applications (e.g. enlarge circle of friends, stay in contact with friends, communicate, exchange pictures or videos, have fun by playing online games) are utilized by which SNS users. In doing so it could be investigated which reasons or perceptions are responsible for such a SNS behavior. Furthermore, the usefulness of social network sites is essential for people to register in such communities. Consequently it would be interesting to know which services are explicitly most important for elderly people. Apart from that, the correlation between Perceived Ease of Use and Intention discloses a certain level of PC and internet skills.

In terms of practical implications this research shows that adopters and non-adopters are different regarding their motivation to adopt or not to adopt SNS. Given that it is important to motivate elderly people to participate in those networks one should focus on describing the Utilitarian Outcomes and by allaying the fear of technologies. As these two aspects are the most important perceptions for those who do not want to use SNS in the future. In contrast those who have experience with SNS point out that they perceive positive Utilitarian Outcomes, that the platforms are easy to use and do not perceive as much as nonadopters a fear due to the technology. In addition their normative beliefs encourage them to continue using SNS. Therefore for SNS provider for elderly people it is important to point out the usefulness of their platforms as feierabend.de does by establishing regional groups and supporting offline activates of the users. Moreover the Fear of Technology can be addressed as feierabend.de does by explicitly focusing on explaining and supporting the usage of the platform. This is a first step towards an age-sensitive design of online services as demanded by Pak et al. 2009 [60], which reveals that online services for elderly people should be connected with offline activities in order to support the use and usefulness of these platforms.

\section{Conclusion}

Why do elderly people adopt or not adopt SNS, is the main research question of this research. By using MATH the results indicate that adopters are mainly driven by Utilitarian Outcomes, Normative Beliefs, Perceived Ease of Use and Fear of Technology and non-adopters by Utilitarian Outcomes and Fear of Technology. As a consequence the research provides evidence that beside the moderator age within the math it is important to consider the difference between adopters and non-adopters within the group of elderly persons as well.

\section{REFERENCES}

[1] (N)Onliner Atlas: Eine Topographie des digitalen Grabens durch Deutschland: Nutzung und Nichtnutzung des Internets, Strukturen und regionale Verteilung. In: TNS Infratest Juni, München (2009).

[2] Ajzen, I.: The theory of planned behavior. In: Organizational Behavior and Human Decision Processes 50 (1991) 2, S. 179211.

[3] Ajzen, I.; Fishbein, M.: Understanding attitudes and predicting social behavior. Englewood Cliffs, NJ 1980.

[4] Azari, R.; Pick, J. B.: Technology and society: socioeconomic influences on technological sectors for United States counties. In: International Journal of Information Management 25 (2005) 1, S. 21-37.

[5] Bagozzi, R. P.: The Role of Measurement in Theory Construction and Hypothesis Testing: Toward a Holistic Model. In: Ferrell, O. C.; Brown, S. W.; Lamb, C. W. (Hrsg.): Conceptual and theoretical developments in marketing. Chicago, Ill. 1979.

[6] Bagozzi, R. P.; Yi, Y.: On the Evaluation of Structural Equation Models. In: Journal of the Academy of Marketing Science 16 (1998) 1, S. 74-94.

[7] Bhattacherjee, A.; Hikmet, N.: Physicians' resistance toward healthcare information technology: a theoretical model an empirical test. In: European Journal of Information Systems 16 (2007) 6, S. 725-37.

[8] Bhattacherjee, A.; Hikmet, N.: Physicians' Resistance toward Healthcare Information Technologies: A Dual-Factor Model. In: Hawaii International Conference on System Sciences (2007).

[9] Bhattacherjee, A.; Sanford, C.: Influence Processes for Information Technology Acceptance: An Elaboration Likelihood Model. In: MIS Quarterly 30 (2006) 4, S. 805-25.

[10] BitKom: 30 Millionen Deutsche sind Mitglieder in Communitys.

URL: http://www.bitkom.org/de/themen/36444_62772.aspx. Abrufdatum 21.08.2010.

[11] Blackwell, A. F.: End-user Developers at Home. In: Communications of the ACM 47 (2004) 9, S. 65-66.

[12] Brown, S. A.: Household Technology Adoption, Use, and Impacts: Past, Present, and Future. In: Information Systems Frontiers 10 (2008) 4, S. 397-402.

[13] Brown, S. A.; Venkatesh, V.: Model of Adoption of Technology in Households: A Baseline Model Test and Extension Incorporating Household Life Cycle. In: MIS Quarterly 29 (2005) 3, S. 399-426.

[14] Campell, D. T.; Fiske, D. W.: Convergent and discriminant validation by the multitrait-multimethod matrix. In: Psychological Bulletin 56 (1959) 2, S. 81-105.

[15] Carmines, E. G.; Zeller, R. A.: Reliability and validity assessment, [Nachdr.]. Newbury Park, Calif. 2008.

[16] Cenfetelli, R. T.: Inhibitors and Enablers as Dual Factor Concepts in Technology Usage. In: Journal of the Association for Information Systems 5 (2004) 11-12, S. 472-92.

[17] Chin, W. W.: The Partial Least Squares Approach to Structural Equation Modeling. In: Marcoulides, G. A. (Hrsg.): Modern methods for business research. Mahwah N.J. u.a. 1998.

[18] Chin, W. W.; Dibbern, J.: An Introduction to a Permutation Based Procedure for Multi-Group PLS Analysis: Results of Tests of Differences on Simulated Data and a Cross Cultural Analysis of the Sourcing of Information System Services Between Germany and the USA. In: Esposito Vinzi, V.; Chin, W. W.; Henseler, J.; Wang, H. (Hrsg.): Handbook of Partial Least Squares. Concepts, Methods and Applications. Berlin, Heidelberg 2010. 
[19] Chin, W. W.; Johnson, N.; Schwarz, A.: A fast form approach to measuring technology acceptance and other constructs. In: MIS Quarterly 32 (2008) 4, S. 687-703.

[20] Chin, W. W.; Newsted, P. R.: Structural Equation Modeling analysis with Small Samples Using Partial Least Squares. In: Hoyle, R. H. (Hrsg.): Statistical strategies for small sample research. Thousand Oaks, Calif. 2000.

[21] Choudrie, J.; Dwivedi, Y. K.: Investigating Factors Influencing Adoption of Broadband in the household. In: Journal of Computer Information Systems 46 (2006) 4, S. 25-34.

[22] Choudrie, J.; Lee, H. J.: Broadband development in South Korea: institutional and cultural factors. In: European Journal of Information Systems 13 (2004) 2, S. 103-14.

[23] COMPASS HEADING: Nutzerzahlen Sozialer Netzwerke Januar 2010. URL: http://www.compassheading.de/cms/nutzerzahlen-sozialer-netzwerke-januar-2010/. Abrufdatum 21.08.2010.

[24] Correa, T.; Hinsley, A. W.; de Zúniga, H. G.: Who interacts on the Web?: The intersection of users' personality and social media use. In: Computers in Human Behavior 26 (2010), S. 247-53.

[25] Dewan, S.; Riggins, F. J.: The Digital Divide: Current and Future Research Directions. In: Journal of the Association for Information Systems 6 (2005) 13.

[26] Dwivedi, Y. K.; Choudrie, J.; Brinkman, W.-P.: Development of a survey instrument to examine consumer adoption of broadband. In: Industrial Management \& Data Systems 106 (2006) 5, S. 700-18.

[27] Eckhardt, A.; Laumer Sven; Weitzel, T.: Who influences whom Analyzing workplace referents' social influence on IT adoption and non-adoption. In: Journal of Information Technology 24 (2009) 1, S. 11-24.

[28] Ellison, N.; Steinfield, C.; Lampe, C. A. .: The Benefits of Facebook "Friends:" Social Capital and College Students' Use of Online Social Network Sites. In: Journal of ComputerMediated Communication 12 (2007) 4, S. 1143-68.

[29] Enns, H. g.; Huff, S. L.; Higgins, C. A.: CIO Lateral Influence Behaviors: Gaining Peers' Commitment to Strategic Information Systems. In: MIS Quarterly 27 (2003) 1, S. 15576.

Facebook:

Statistics.

URL: http://www.facebook.com/press/info.php?statistics.

Abrufdatum 01.07.2010

[31] Fishbein, M.; Ajzen, I.: Belief, attitude, intention and behavior. An introduction to theory and research. Reading, Mass. 1975.

[32] Fornell, C.; Larcker, D. F.: Evaluating Structural equation models with unobservable variables and measurement error. In: Journal of Marketing Research 18 (1981) 1, S. 39-50.

[33] Gallivan M.J.; Srite, M.: Information Technology and Culture: Identifying Fragmented and Holistic Perspectives of Culture. In: Information \& Organization 15 (2005) 2, S. 295-338.

[34] Hargittai, E.: Second-Level Digital Divide: Differences in People's Online Skills. URL: http://www.firstmonday.dk/issues/issue7_4/hargittai.

[35] Henseler, J.; Ringle, C. M.; Sinkovics Rudolf R.: The use of partial least squares path modeling in international marketing. In: Advances in International Marketing 20 (2009), S. $277-$ 319.

[36] Hirschheim, R.; Newman, M.: Information Systems and User Resistance: Theory and Practice. In: The Computer Journal 31 (1988) 5, S. 398-408.

[37] Holznagel, B.: Frequenzeffizienz und Rundfunkspektrum. In: MMR (2008) 4, S. 207-15.

[38] Hulland, J. S.: Use of partial least squares (PLS) in strategic management research: A review of four recent studies. In: Strategic Management Journal 20 (1999) 2, S. 195-204.
[39] Hutter, T.: Facebook Demographische Zahlen der Länder > 1 Mio. Benutzer per 31.05.2010 (2010). URL: www.thomashutter.cin

[40] Jiang, J. J.; Muhanna, W. A.; Klein, G.: User resistance and strategies for promoting acceptance across system types. In: Information and Management 37 (2000) 3, S. 25-36.

[41] Johansen, R.; Swigart, R.: Upsizing the individual in the downsized organization. Managing in the wake of reengineering, globalization, and overwhelming technological change. Reading, Mass 1996.

[42] Jones, Q.; Ravid, G.; Rafaeli, S.: Information Overload and the Message Dynamics of Online Interaction Spaces: A theoretical model and empirical exploration. In: Information Systems Research 15 (2004) 2, S. 194-210.

[43] Joos, J. G.: Social media: New frontiers in hiring and recruiting. In: Employment Relations Today 35 (2008) 1, S $51-59$.

[44] Khan, Z.; Jarvenpaa, S. L.: Exploring temporal coordination of events with Facebook.com. In: Journal of Information Technology 25 (2010) 2, S. 137-51.

[45] Kim, H.-W.; Kankanhalli, A.: Investigating User Resistance to Information Systems Implementation: A Status Quo Bias Perspective. In: MIS Quarterly 33 (2009) 3, S. 567-82.

[46] Kubicek, H.; Welling, S.: Vor einer digitalen Spaltung in Deutschland? Annäherung an ein verdecktes Problem von wirtschafts- und gesellschaftspolitischer Brisanz. In: Medien und Kommunikationswissenschaft 48 (2000) 4, S. 497-517.

[47] Lapointe, L.; Rivard, S.: A Multilevel Model of Resistance to Information Technology Implementation. In: MIS Quarterly 29 (2005) 3, S. 461-91.

[48] Laumer, S.; Maier, C.; Eckhardt, A.: Towards an Understanding of an Individual's Resistance to Use an IS Empirical Examinations and Directions for Future Research. Phoenix (AZ) 2009.

[49] Laumer, S.; Maier, C.; Eckhardt, A.: Why do they resist? - An empirical analysis of an individual's personality trait resistance regarding the adoption of new information systems. European Conference on Information Systems, South Africa 2010.

[50] Lewin, K.: Frontiers in Group Dynamics: Concept, Method and Reality in Social Science; Social Equilibria and Social Change. In: Human Relations 1 (1947) 1, S. 5-41.

[51] Lewis, K.; Kaufman, J.; Christakis, N.: The Taste for Privacy: An Analysis of College Student Privacy Settings in an Online Social Network. In: Journal of Computer-Mediated Communication 14 (2008) 1, S. 79-100.

[52] Lewis, K.; Kaufman, J.; Gonzales, M.; Wimmer, A.; Christakis, N.: Taste, Ties, and Time: A new social network dataset using Facebook.com. In: Social Networks 30 (2008) 4, S. $330-42$.

[53] Luftman, J.; Kempaiah, R.; Rigoni E. H.: Key Issues for IT Executives 2008. In: MIS Quarterly Executive 8 (2009) 3, S. 151-59.

[54] Markus, M. L.: Power, Politics, and MIS Implementation. In: Communications of the ACM 26 (1983) 6, S. 430-44.

[55] Mayer, A.; Puller, S.: The Old Boy (and Girl) Network: Social network formation on university campuses. In: Journal of Public Economics 92 (2008) 1-2, S. 329-47.

[56] Mertens, P.: Fehlschläge bei IT-Großprojekten der öffentlichen Verwaltung - ein Beitrag zur Misserfolgsforschung in der Wirtschaftsinformatik. München 2008.

[57] Moore, G. A.: Crossing the chasm. Marketing and selling hightech products to mainstream customers, Rev. ed. New York 1999.

[58] Norman, D. A.: Things that make us smart. Defending human attributes in the age of the machine, [10. print.]. Reading, Mass. 1999. 
[59] Oreg, S.: Resistance to Change: Developing an Individual Differences Measure. In: Journal of Applied Psychology 88 (2003) 4, S. 680-93.

[60] Pak, R.; Price, M.; Thatcher, J. B.: Age-Sensitive Design of Online Health Information: Comparative Usability Study. In: Journal of Medical Internet Research 11 (2009) 4.

[61] Phang, C. W.; Kankanhalli, A.; Sabherwal, R.: Usability and Sociability in Online Communities. In: Journal of the Association for Information Systems 10 (2009) 10, S. 721-47.

[62] Raacke, J.; Bonds-Raacke, J.: MySpace and Facebook: Applying the Uses and Gratifications Theory to Exploring Friend-Networking Sites. In: CyperPsychology \& Behavior 11 (2008) 2, S. 169-74.

[63] Ringle, C. M.; Wende, S.; Will, A.: SmartPLS, 2.0 (beta) 2005.

[64] Rosen, P.; Sherman, P.: Hedonic Information Systems: Acceptance of Social Networking Websites. Mexiko 2006.

[65] Ross, C.; Orr, E. S.; Sisic, M.; Arseneault, J. M.; Simmering, M. G.; Orr, R. R.: Personality and motivations associated with Facebook use. In: Computers in Human Behavior 25 (2009) 2, S. $578-86$. studiVZ:

\section{Data}

and

Facts. URL: http://www.studivz.net///about_us/1/. Abrufdatum 14.07.2010.

[67] Subrahmanyam, K.; Reich, S. M.; Waechter, N.; Espinoza, G.: Online and offline social networks: Use of social networking sites by emerging adults. In: Journal of Applied Developmental Psychology 29 (2008) 6, S. 420-33.

[68] Valenzuela, S.; Park, N.; Kee. K. F.: Is there social capital in a social network site? Facebook use, and college students' life satisfaction, trust, and participation. In: Journal of ComputerMediated Communication 14 (2009) 4, S. 875-901.
[69] Venkatesh, A.: Digital home technologies and transformation of households. In: Information Systems Frontiers 10 (2008) 4, S. 391-95.

[70] Venkatesh, V.; Brown, S. A.: A Longitudinal Investigation of Personal Computers in Homes: Adoption Determinants and Emerging Challenges. In: MIS Quarterly 25 (2001) 1, S. 71102.

[71] Venkatesh, V.; Morris, M. G.; Davis, G. B.; Davis, F. D.: User Acceptance of Information Technology: Toward a unified View. In: MIS Quarterly 27 (2003) 3, S. 425-78.

[72] Walther, J. B.; Van der Heide, B.; Kim, S.-Y.; Westerman, D.; Tong, S. T.: The Role of Friends' Appearance and Behavior on Evaluations of Individuals on Facebook: Are We Known by the Company We Keep? In: Human Communication Research 34 (2008) 1, S. 28-49.

[73] Wege ins Netz: Der Wettbewerb für mehr digitale Kompetenz (2010).

URL: http://www.bmwi.de/BMWi/Navigation/Technologieund-Innovation/Informationsgesellschaft/interneterfahren,did=339642.html. Abrufdatum 21.08.2010.

[74] Weitzel, T.; Eckhardt, A.; Laumer, S.: A Framework for Recruiting IT Talent: Lessons from Siemens. In: MIS Quarterly Executive 8 (2009) 4, S. 175-89.

[75] Wiener, L. R.: Digital woes. Why we should not depend on software. Reading, Mass 1993.

[76] Williams, M. D.; Dwivedi, Y. K.; Lal, B.; Schwarz, A. Contemporary trends and issues in IT adoption and diffusion research. In: Journal of Information Technology 24 (2009) 1 , S.

1-10. 